\title{
バイモルフ型ピエゾ部材で出カ補強される 積層型素子駆動変位拡大機構*
}

\author{
小泉邦雄 ${ }^{* *}$ 笹木 亮** 佐々木基文*** 岡部佐規一 ${ }^{\dagger}$ 横山恭男 ${ }^{+1}$
}

Piezo-stack Driven Type Displacement Magnification Mechanism

Reinforced by Bimorph Piezoelectric Members

Kunio KOIZUMI, Tohru SASAKI, Motofumi SASAKI, Saki-ichi OKABE and Yasuo YOKOYAMA

\begin{abstract}
This paper deals with fundamental characteristic of the mechanism which consists of lever and toggle mechanisms. The mechanism is chiefly actuated by twin multilayer piezoelectric actuators. It can locate minutely and quickly for mechanical working and handling of some minute and thin objects. The lever members were made from a bimorph type piezoelectric actuator. As they were connected by elastic joints, the mechanism has no clearance and no friction. The mechanism is based on two concepts. In the first, mechanical stiffness of the members is variable and reinforced by additional electrical stiffness due to actuation of the bimorph members. Therefore the members can take smaller mechanical stiffness and inertia. The second, it can be variable input-output characteristic of a piezo-stack actuator and correct deviated position of an output point by additional actuation of the bimorph members. With the experimental mechanism, the resolution is $1.57 \mu \mathrm{m}$.
\end{abstract}

Key words : displacement magnification, flexible mechanism, bimorph type piezoelectric actuator, multilayer piezoelectric actuator

1. 緒亭

楀層型ピエソ秦子は，高い忘答性を持ち，微小変位と大きな 力が得られるアクチュエータとして，精密位置決めを要する加工 やハンドリング技術に広く応用されている。その扗力特性は，発 生する力に対して変位が非常に小さく(12)，アンバランスであるた

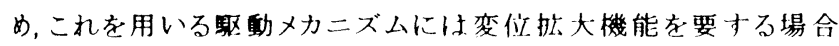
が多い，変位払大機桡としては，レバーの組合せが多く，座屈を

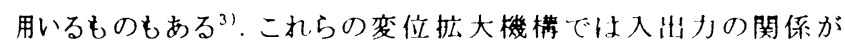
一義的に決まり，出力特性を任意に変化させることはできない，

本研究ではレバーとトタルを組合せた一体形状のシム材にピ エソ板”を貼り, 各部をバイモルフ部材で構成した機䊔で稹層型 素子の変位を抗大し，さらにハハイモルフ部材で出力を補強与るつ レキシブルな棈造を提案して，検郡を加えた。従来ひリンク機棈 では, 入力変位に対する出力の変位上力の関係が固定さ机てい

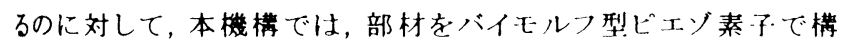
成し，発生する曲げモーメントで機械的㓮性を補い，出力特性を 可変とし，任意の力と変位の出力が得られる，さらに，曲げモーメ ントを動的に変化させたり，個々の部材を独立に駆動寸すことで, 出力点を2次元的に動かすフレキシビリティを持た寸ことができる。 また，機棈の奥行が部材の幅程度に㧕えられるため，多数をコン パクトに並列配置できるので, 順送型微小機满にも適している。

本報では，変位抬大機粠の基本動作特性在解析し，バイモル フ部材の駆動による楮層型素子の特性の変化について述べる。

\footnotetext{
* 原稿受付平成 9 年 2 月 17 日

*正会員富山大学工学部(富山市五福3190)

*富山大学工学部

†正会会 金沢大学工学部(金沢市小立野2-40-20)

H 正会員石川工亲高等尃門学校 (石川県河北郡津幡町北中条)
}

2. 記 号

$f_{\text {in }}, x_{\text {in }}$ : 入力の力および変位, $f_{\text {out }}, y_{\text {out }}$ : 出力の力および変位, $\left(f_{\text {in }}\right)_{\text {max }},\left(x_{\text {in }}\right)_{\text {max }}$ : 䅡層型素子の最大発生力抢よび変位, $m_{o a}, m_{o b}$ : レバー部とトグル部のバイモルフ部材の発生曲げモーメント， $E I_{i}$ :

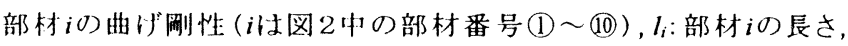
$\theta_{a}, \theta_{b}:$ レ゙ー部よトグル部のオフセット角, $f_{j}, m_{o j}$ : 節点 $j(j$ は図 2中の節点 $\Lambda$ K ) に作用する反力および反モーメント， $u_{j}, \theta_{j}$ : 節 点 $j$ の部分座標に拈计るたわみとたわみ角， $f_{x}$ : 節点 Kに作用する $x$ 軸力向のカ, $t$ : バイモルフ部材の全厚さ, $t_{\mathrm{c}}$ : シム材の厚さ, $b$ : 部材け幅, $\mathrm{e}$ :压電忘力定数, $d_{3 l}$ : 圧電ひずみ定数, $v_{\text {in }},\left(v_{\text {in }}\right)_{\text {max }}$ : 筫層型素子・の)印加電压および最大電圧, $v_{\text {in }}{ }^{\prime}$ : バイモルフ部材の 印加電压， $k_{x}$ :入出力点間の㓮性, $2 w_{x}: k_{x}$ に蓄えら孔るエネルギー,

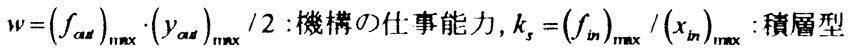
素子㪀機械的㴊性, $l_{a}=l_{1}+l_{2}+l_{3}+l_{4}+l_{5}, l_{b}=l_{6}+l_{7}+l_{8}, l_{c}=l_{9}+l_{10}$ しして, 無次元量を $L_{1}=l_{1} / l_{4}, K_{1}=E I_{1} / E I_{4}, X_{\text {in }}=x_{\text {in }} / l_{4}, Y_{\text {out }}=y_{\text {out }} / l_{4}$,

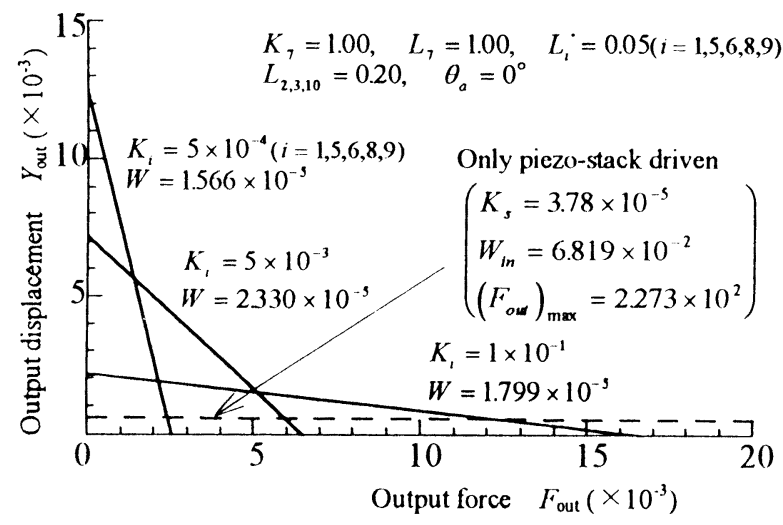

Fig.1 Output characteristic of actuator with the mechanism 


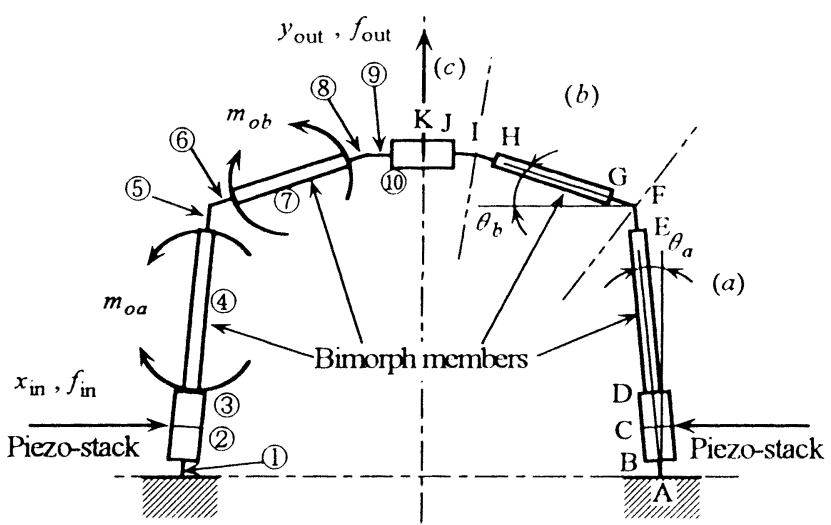

Fig.2 Principle model of mechanism

$V_{\text {in }}=v_{\text {tn }} /\left(v_{\text {tn }}\right)_{\max }, F_{j}=f_{J} /\left(E I_{4} / l_{4}{ }^{2}\right), M_{O J}=m_{O J} /\left(E I_{4} / l_{4}\right)$, $K_{s}=k_{s} \cdot l_{4}^{3} / E I_{4}, K_{x}=k_{x} \cdot l_{4}^{3} / E I_{4}, W=w /\left(E I_{4} / l_{4}\right)$ とする.

\section{3. 取 動 原 理}

積層型素子は，印加電圧で発生する変位と力の関係が直線 的に変化するが, 変位が微小で力が大きいため,これを図1に示 寸と，破線のように力に偏ったアンバランスな関係となっている. ここで記号は2で定義した無次元量である。変位抬大機構を用い て，実線のようにこの出力の変位と力の関係をバランスのよい状 態に変換できれば, 楮層型素子の発生変位を增大させ, 目的に 忘した出力特性が得られる，本機粠は，図2に示すような形状を しており，(a)部の両側下部の対向した積層型素子に入力を加え て水平方向の変位 $x_{\text {in }}$, 力f $f_{\text {in }}$ 生しさせる. (a)のレバー部で1段目 の変位抬大をした後, (b)のトグル部で2段目の変位拗大をして

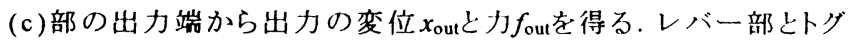
ル部の結合には弾性関節を用いて,ガタや摩擦を除いている。 図3の破線のように,レバー部とトグル部のバイモルフ部材を駆動 しないとき，部材の曲げ刚性が小さいために，たわぬが大きく，出 力変位は減少する。この部材のたわみを城らして元に戻才方向 にバイモルフ部材を駆動することで，1点鎖線のように剛性の低 下が補供され，出力を補強できる。このように,バイモルフ部材の 印加電圧で部材の曲价㓮性を変化できるので, 機構の機械的㓮 性を補供して, 積層型素子の出力特性が可変となり, 発生す心゙ き力と変位が得られる.また，バイモルフ部材を独立に駆動すれ は，製作誤差による出力点動作の芯のずれ，傾きおよび，蛇行 等の補正が可能となる. 主俚動源である積層型素子とバイモルフ 部材との眐動機能の分担が可能となり，残留振動の㧕止や高周 波振動の重畳など, フレキシブルな動作が可能である.

\section{4. 動 作}

図2に示寸モテルの形状と材質は左右対称であり, 楮層型素 子および各バイモルフ部材に作用する力およびモーメントも含ぬ， 部材 (1)〜 (10)を部分 (a)，(b)，(c)に分け，はり要素として各節点A 〜 Kのたわみを計算する。つぎに，直楾部(b)の部分座標の原点 を(a)の端点に，(c)の原点を(b)の端点にそれぞれ移動し，各部 のはりの端のたわみとたわみ角を求めて，その和より出力点の絶 対変位と角度が得られる.これより, 機構の入出力特性を求める。

$\mathrm{A}-\mathrm{F}$ 間の直線部(a)の端点Fに作用する力およびモーメントを， 出力点における力とモーメントで表すと, 次式となる.

$$
\begin{aligned}
& f_{T}=f_{x} \cos \theta_{a}-\left(f_{\text {out }} / 2\right) \sin \theta_{a} \\
& m_{o F}=l_{b} f_{x} \sin \theta_{b}-\left(f_{\text {out }} / 2\right) \cdot\left(l_{c}+l_{b} \sin O_{b}\right)-m_{o K}
\end{aligned}
$$

$$
\begin{aligned}
& L_{1}=0.05 \\
& L_{2,3,10}=0.20 \\
& L_{4,7}=1.00 \\
& L_{5-6,8-9}=0.05 \\
& \theta_{a}=0.0 \\
& \theta_{b}=15.0 \\
& K_{7}=1.00 \\
& K_{i}=0.05 \\
& (i=1,5,6,8,9)
\end{aligned}
$$

Main actuation point

$F_{\text {in }}, X_{\text {in }}$

(3) Additional actuation on bimorph member

(2) No actuation on bimorph member

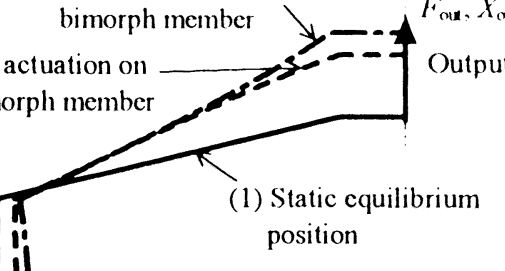

$F_{\text {in }}=0.1, M_{o a}=0.2, M_{o b}=-0.2$

\begin{tabular}{|c|c|c|}
\hline States & $X_{\text {in }}$ & $Y_{\text {out }}$ \\
\hline$(2)$ & $1.93 \times 10^{-4}$ & $2.020 \times 10^{-3}$ \\
\hline$(3)$ & $3.71 \times 10^{-4}$ & $2.649 \times 10^{-3}$ \\
\hline
\end{tabular}

Fig.3 Deflection of member in mechanism

ここで,バイモルフ部材に曲げモーメントが発生するが，部材中央 面の上半分についてのユニモルフ部材を仮想して, 部材(a)の厚 み方向に $y$ 軸，幅力向に $z$ 軸をとると，印加電压によって生ずるひ 才゙みでDーE間に発生する曲げモーメントmoaは，次式で表される゙，

$$
m_{o n} / 2=\int_{-b / 2}^{b / 2} d z \int_{c}^{\prime / 2} t^{1 / 2} e \frac{v_{i n}{ }^{\prime}}{t-t_{s}} y d y=(-t / 4) \cdot\left(1+t_{c} / t\right) \cdot e b v_{i n}{ }^{\prime}
$$

このとき，曲げモーメントによる部材のたわみ

$$
u_{D-B}=\left(m_{o a} / 2\right) \cdot l_{4}{ }^{2} / 2 E I_{4}=3(e / E) \cdot\left(l_{4} / t\right)^{2} \cdot\left(1+t_{c} / t\right) \cdot v_{i n}{ }^{\prime} \text { (4) }
$$

ここで，e/Eは与えた電界の強さ当たりの生したひずみ，すなわち 横効果素子ひ压電ひず放定数 $d_{31}$ に等しい. 従って式(3)は

$$
m_{o a}=3 d_{31} \cdot\left(l_{4} / t\right)^{2} \cdot\left(1+t_{c} / t\right) \cdot\left(E I_{4} / l_{4}{ }^{2}\right) \cdot v_{i n}{ }^{\prime}
$$

となり,バイモルフ部材に発生寸るもーメントmoaは卵加電压 $v_{\text {in }}$ に 比例する。.以上のことは直線部(b)についても同様である。

B-D閒は十分大きな哃性を持たせるので，用体とみなす。

D-E間に曲げモーメントmoa゙発生寸るときに，(a)部のF端に発 生するたわみ的とたわみ角 $\theta_{F}$ は

$$
\begin{aligned}
& u_{F}=a_{u 4} f_{i n} \cos \theta_{a}+g_{u 4} f_{K}+b_{u 4} f_{o u} / 2+h_{u 4} m_{o K}+c_{u 4} m_{o o} \\
& \theta_{F}=a_{3} f_{i n} \cos \theta_{a}+g_{g} f_{K}+b_{5} f_{o u} / 2+h_{5} m_{o K}+c_{5} m_{o a}
\end{aligned}
$$

ここで, $a_{u i}, g_{u i}, b_{u i} ， h_{u i}, c_{u i}$ は部材iのたわ加に関する係数， $a_{i}$, $g_{i}, b_{i}, h_{i}, c_{i}$ は，たわ的に関吉る係数である.

同様に(b)，(c)部の端点I，Kのたわみとたわみ角はそれぞれ

$$
\begin{aligned}
& u_{I}=g_{u s} f_{K}+b_{u s} f_{o u t} / 2+h_{u s} m_{o K}+d_{u s} m_{o b} \\
& \theta_{I}=g_{8} f_{K}+b_{8} f_{\text {out }} / 2+h_{8} m_{o K}+d_{8} m_{o b} \\
& u_{K}=h_{u 10} f_{\text {out }} / 2+h_{u 10} m_{o K} \\
& \theta_{K}=b_{10} f_{\text {out }} / 2+h_{10} m_{o K}
\end{aligned}
$$

$d_{u i}, d_{i}$ は，たわみ上たわみ角に関する俰数である，

(b), (c) 部の座標原点を, それぞれ(a), (b)部端点に移動して, 式(6)〜(11)よりたわみとたわみ角を加えると, 出力点 $\mathrm{K} の$ 変位は

$$
\begin{aligned}
& x_{\text {out }}=-u_{F} \cos \theta_{a}-u_{I} \sin \theta_{b}-\theta_{P}\left(l_{b} \sin \theta_{b}\right) \\
& y_{\text {out }}=-u_{P} \sin \theta_{a}-u_{I} \cos \theta_{b}-\theta_{P}\left(l_{b} \cos \theta_{b}+l_{c}\right)-\theta_{I} l_{c}-u_{K} \\
& \theta_{\text {out }}=-\theta_{F}-\theta_{I}-\theta_{K}
\end{aligned}
$$

上なる.形状および駆動を左右対称とすれは，K点で境界条件

$$
\theta_{\text {out }}=0, x_{\text {out }}=0
$$


が成り立つ. 各保数を $a_{n}{ }^{\prime}, b_{n}{ }^{\prime}, d_{n}{ }^{\prime}, c_{n}{ }^{\prime}, g_{n}{ }^{\prime}$ L䁌き直し，式(15)の 第1式より，式(7),(9),(11)を用いて，次式

$$
m_{o K}=a_{1}^{\prime} f_{\text {in }} \cos \theta_{a}+g_{1} f_{K}+b_{1}^{\prime} f_{o u t} / 2+c_{1}^{\prime} m_{o a}+d_{1}^{\prime} m_{o b}
$$

同しく第2式に，式(6),(7),(8)を用いと次式を得る.

$$
f_{x}=a_{2}{ }^{\prime} f_{\text {in }} \cos \theta_{a}+b_{2}{ }^{\prime} f_{o u t} / 2+c_{2}{ }^{\prime} m_{o a}+d_{2}{ }^{\prime} m_{o b}
$$

式(17)を式(16)に代入して，次式となる

$$
\begin{aligned}
m_{o K}= & \left(a_{1}{ }^{\prime}+g_{1}{ }^{\prime} a_{2}{ }^{\prime}\right) f_{\text {in }} \cos \theta_{a}+\left(b_{1}{ }^{\prime}+g_{1}{ }^{\prime} b_{2}{ }^{\prime}\right) f_{o u t} / 2 \\
& +\left(c_{1}{ }^{\prime}+g_{1}{ }^{\prime} c_{2}{ }^{\prime}\right) m_{o a}+\left(d_{1}{ }^{\prime}+g_{1}{ }^{\prime} d_{2}^{\prime}\right) m_{o b}
\end{aligned}
$$

式(6)〜(10)に式(17),(18)を代入して $\boldsymbol{m}_{o K}, f_{x}$ 走消去し，各係数をまとぬ， 無次元化して $A_{n}, B_{n}, C_{n}, D_{n}$ と表主上, 人力変位 $X_{\text {in }}$ と出力変位 $Y_{\text {oul }}$ L 次式のように, $F_{\text {out }}, F_{\text {in }}, M_{\text {oa }}$ およ゙゙ $M_{\text {ob }}$ んいての1次結合で表せる.

$$
Y_{\text {out }}=A_{1} F_{\text {in }}+B_{1} F_{o u t}+C_{1} M_{o b}+D_{1} M_{o b}
$$

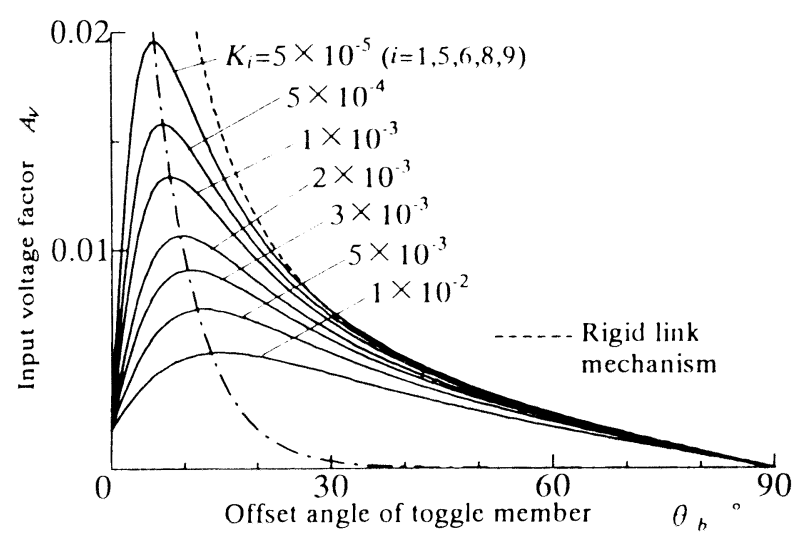

(a) Input voltage factor

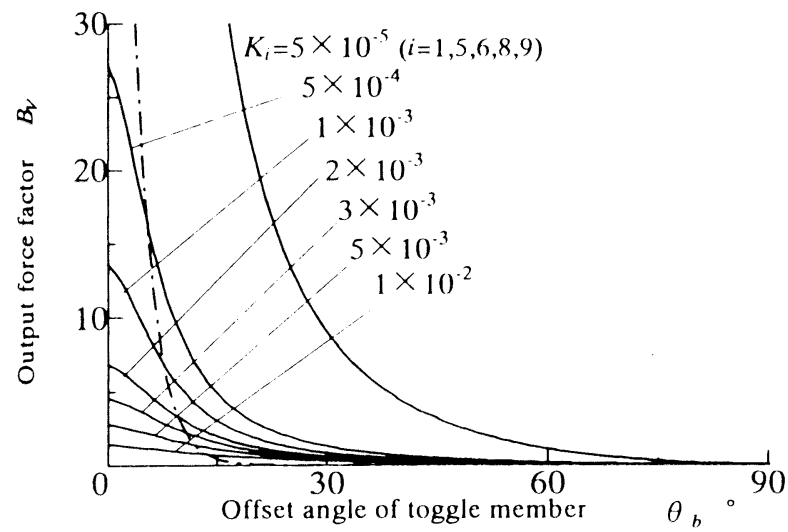

(b) Output force factor

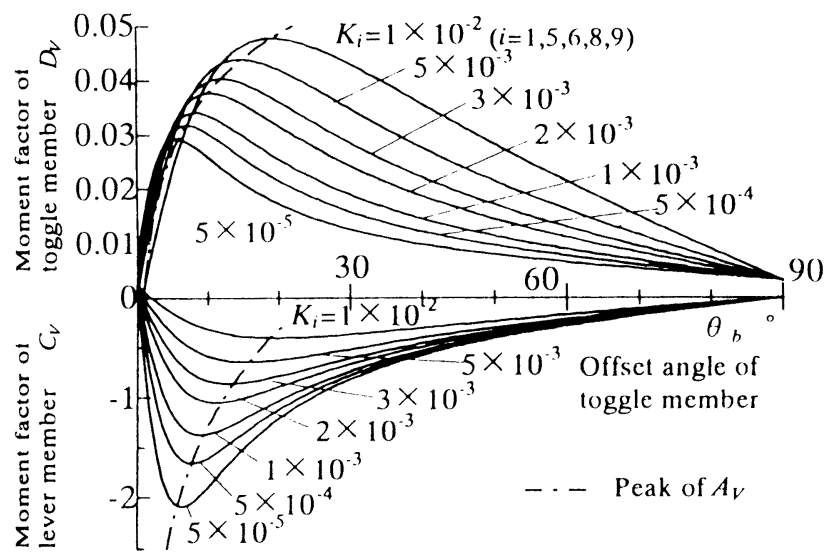

(c) Moment factors of lever and toggle member

$K_{7}=1.00, L_{7}=1.00, L_{i}=0.05(i-1,5,6,8,9), L_{2,3,10}=0.20, \theta_{a}=0^{\circ}$

Fig.4 Change of coefficient with altaching angle of toggle member

$$
X_{\text {in }}=A_{2} F_{1 n}+B_{2} F_{o u t}+C_{2} M_{o a}+D_{2} M_{o b}
$$

ここで, 図1のような，楀層型素子が発生する変位と力の直線的な 関係は，次式で表される。

$$
F_{i n}=K_{s}\left\{\left(X_{i n}\right)_{m} \cdot V_{i n}-X_{i n}\right\}
$$

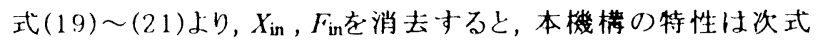

$$
\Xi \equiv Y_{\text {out }}+B_{v} F_{\text {out }}=A_{v} V_{\text {in }}+C_{v} M_{o s}+D_{v} M_{\text {ob }}
$$

で示される.ただし，

$$
\begin{aligned}
& A_{v}=\frac{A_{1}\left(F_{\text {in }}\right)_{\text {max }} \cdot\left(X_{\text {in }}\right)_{\text {max }}}{A_{2}\left(F_{\text {in }}\right)_{\text {max }}+\left(X_{\text {in }}\right)_{\text {max }}}, B_{v}=B_{2} \frac{A_{1}\left(F_{\text {in }}\right)_{\text {max }}}{A_{2}\left(F_{\text {in }}\right)_{\text {max }}+\left(X_{\text {in }}\right)_{\text {max }}}-B_{1}, \\
& C_{v}=C_{1}-C_{2} \frac{A_{1}\left(F_{i n}\right)_{\max }}{A_{2}\left(F_{i n}\right)_{\max }+\left(X_{i n}\right)_{\max }}, D_{v}=D_{1}-D_{2} \frac{A_{1}\left(F_{i n}\right)_{\max }}{A_{2}\left(F_{i n}\right)_{\max }+\left(X_{i n}\right)_{\max }}
\end{aligned}
$$

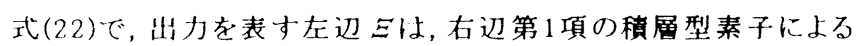

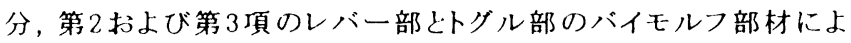
る分の和であることを示している. 左辺第 1 項 0 出力変位 $Y_{\text {out }}$ 大 きく取札ば，その分，第2項の発生力F $F_{\text {oul }}$ は堿少することになる.

糟層型素子による出力係数 $A_{\mathrm{v}}$ は, 印加する電圧 $V_{\mathrm{in}}$ の比例係数 であり，図4(a)の1点鎖線ように，極大となるトグル部材のオフセッ 卜角 $\theta_{\mathrm{b}}$ が存在子る. 破線で示子剛体部材のリンク機槽に比べ， 部材のたすみと弾性関節のための損失で， $A_{\mathrm{v}}$ は小さくなるが，関 節の曲げ哃性 $K_{i}$ を小さくすれば，低下を揤えられる，機棈全体の

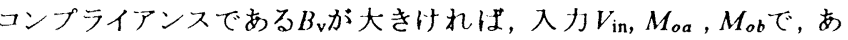
る出力変位 $Y_{\text {out }}$ の)さに，発生力 $F_{\text {out }}$ は小さくなる. 同図(b)のよう に，関節の曲げ刷性 $K_{i}$ を小さくずれば， $A_{\mathrm{v}}$ と同様に增大する。 た,レバー部およびトグル部のバイモルフ部材が発生するモーメ ントM $M_{o a} お よ ひ ゙ M_{o b}$ の出力係数である $C_{\mathrm{v}}, D_{\mathrm{v}}$ は同図(c)のように，両 者の絶対值は 1 点銷楾で示す $A_{\mathrm{v}}$ が極大となるオフセット角でほぼ 極大となり，発生モーメントが効率よく働くので好都合である.

ここでは，Avが極大となるトグル部材のオフセット角を最適角と して後述の設計に用いることにする． $D_{\mathrm{v}}$ は $C_{\mathrm{v}}$ に比べて小さいので， 出力の補強はレバー部材で行い,トグル部材の駆動は, 出力点の芯出 しや高周波振動ひ重疊など，付加的に用いるのが良い。

䄼層型素子だけによる駆動は $M_{o a}, M_{o b}=0$ の場合であり,このと きの式(22)の左辺を機構の出力至とする.これにレバー部材の 発生モーメントが付加された出力 $\Xi_{A, C}$ は, $M_{o b}=0$ の場合であり、卜 少部材が付加された出力 $\Xi_{A, D}$ は, $M_{o a}=0$ の場合である

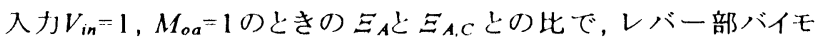
ルフ部材の駆動で出力補強するブースト効果を表すと, 次式

$\Xi_{A, C} / \Xi_{A}=1+C_{V} / A_{V}$,

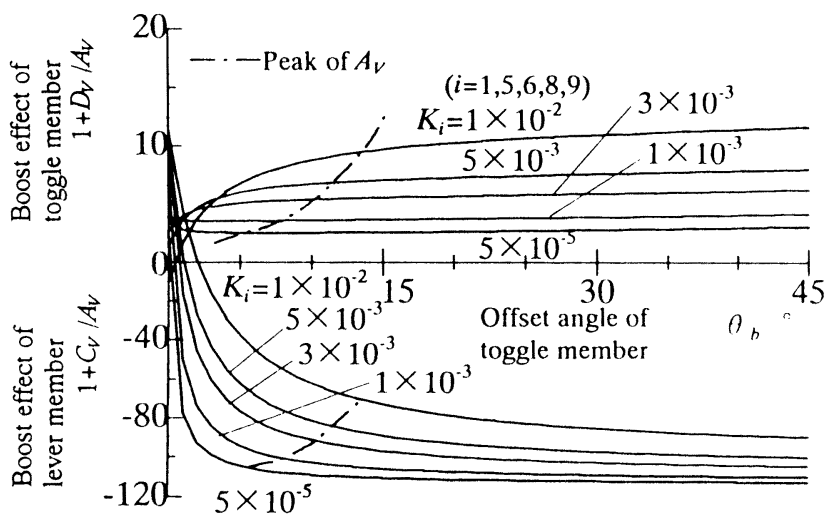

$K_{7}=1.00, L_{7}=1.00, L_{i}=0.05(i=1,5,6,8,9), L_{2,3,0}=0.20, \theta_{a}=0^{\circ}$

Fig.5 Change of boost effect with offset angle of toggle member 
同様に,トグル部バイモルフ部材の駆動によるブースト効果は，

$$
\Xi_{1, D} / \Xi_{A}=1+D_{V} / A_{v}
$$

となる. 図5の縋軸の絶対値はレバー部のバイモルフ部材の駆動 によるブースト効果の大きさを，符号はモーメントの向きを表ず. 図中の 1 点鎖線は糟層型素子の出力係数 $A_{\mathrm{v}}$ が極大となる最適角 であり，オフセット角を大きくするとブースト効果が增すが，この最 適角以上ではオフセット角を大きくする意味が薄れるので，トグル 部材のオフセット角は最適角にとるのがよいと思われる.トグル部 材のブースト効果も同様に，最適角以上では変化が少ない。

\section{5. 機 粠 の 設 計}

パイモルフ部を㽖動するとき，最大発生変位および最大発生 力は, 式(22)で, $F_{\text {out }}=0, Y_{\text {out }}=0$ として, それぞれ次式で表せる。

$$
\left(Y_{\text {out }}\right)_{\text {max }}=A_{v},\left(F_{\text {out }}\right)_{\text {max }}=A_{v} / B_{v}
$$

ある入力で発生する変位と力を同時に大きくすることはできない ため, 図1のように発生力と変位の特性線が囲む面積で, 仕事の 能力Wを評価する. $\left.K_{i}(i=1,5,6,8,9) \sigma\right)$ 值によって特性線の傾きが変わ るため， $K_{i}$ の選び方で， $Y_{\text {out }}$ と $F_{\text {out }}$ の関係を任意に定めることができ る、Wは機構に蓄えられるエネルギーをも表し，次式となる。

$$
W=\left(F_{\text {out }}\right)_{\max } \cdot\left(Y_{\text {out }}\right)_{\max } / 2 \equiv w \cdot\left(E I_{4} / l_{4}\right) / 2
$$

吅体部材を用いたリンク機棈ならば，関節の曲け㓮性は無く， 無関係ゆえW一定であるが，本機椣では，部材がたわむので一 定とならず，図6のようにWを極大とする $K_{i}$ の值が存在する。また $K_{i}$ が小さければ, 関節長さ $L_{i}(i=1,5,6,8,9) に よ り$ 部材のたわみが変わり， $W か ゙$ 変化するため, $L_{i} と K_{i} に$ 対して，Wは極大值を持っＷO）極大 条件での最大出力の変位 $\left(Y_{\text {out }}\right)_{\max }$ および力 $\left(F_{\text {out }}\right)_{\max }$ を図 $7(\mathrm{a})$ に，こ

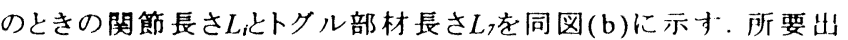
力として，ある $\left(Y_{\text {out }}\right)_{\max }$ と $\left(F_{\text {out }}\right)_{\max }$ が設計条件として与えられた場合， 図(a)から $\theta_{b}, K_{i}$ が得られ，二れより図(b)から $L_{i}, L$, が求められる。

本機粠の入出力点間の刚性 $K_{x}$ を積層型素子の負荷は敉之考 えると，入力点に作用する力は次式となる.

$F_{\text {in }}=K_{x} \cdot X_{\text {in }}$

これは素子側の式(21)と等しく, 機桡に蓄えられるエネルギーは5

$$
W_{x}=\left\{K_{s} K_{x}{ }^{2} / 2\left(K_{s}+K_{x}\right)^{2}\right\}\left(X_{t n}\right)_{\max }^{2}
$$

$W_{x}$ は $K_{x}=K_{s}$ で, 次の極大值をとる。

$$
\left(W_{x}\right)_{\max }=\left(F_{\text {in }}\right)_{\text {max }} \cdot\left(X_{\text {in }}\right)_{\text {max }} / 8
$$

ある電圧での積層型素子単体の伐事能力 $\boldsymbol{w}_{\text {in }}$ は次式で定義される

$$
W_{i n}=\left(F_{\text {in }}\right)_{\max } \cdot\left(X_{i n}\right)_{\max } / 2
$$

したがって，糟層型素子から取り出せる出力エネルギーの極大值は，

稹層型素子の仕事能力の1/4である. 本機構は積層型素子を2個用 いるので $\left(W_{x}\right)_{\max }$ の2倍が機粠の持つ仕事能力の極大值であることから，

$$
W \leq 2\left(W_{x}\right)_{\max }
$$

したがって, 式(26)および(29)より，次の関係が得られる.

$$
\left(F_{\text {out }}\right)_{\text {max }} \cdot\left(Y_{\text {out }}\right)_{\text {max }} \leq\left(F_{\text {in }}\right)_{\text {max }} \cdot\left(X_{\text {in }}\right)_{\text {max }} / 2
$$

本機棈を用いて，積層型素子の特性を改変しようとするとさ， 目的の所要特性は式(32)の条件を満たさなけ机ばならない。

図8に示寸設計手順では，まず，式(32)を満たす $\left(Y_{\text {out }}\right)_{\text {max }} ，\left(F_{\text {out }}\right)_{\text {max }}$ 決め，機棬全体の大きさを考虑して基本となるレバー部材(4)の寸法之 曲げ刚性を定める。つぎに，図7を用いて $\left(Y_{\text {out }}\right)_{\max },\left(F_{\text {out }}\right)_{\text {max }}$ の交点から $\theta_{h}, K_{i}, L_{i}(i-1,5,6,8,9)$ およびL,を求め), 機構の諸元が決定されいる。

$$
\text { 6. 実 }
$$

前述の設計手洼で試作した变位抗大機構を图96示寸。曲价 成形したりん青銅のシム材 $(\mathrm{t} 0.25 \times 9 \mathrm{~mm}) 0) 4$ か所にPZT板（村田

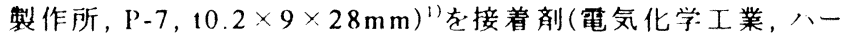
ドロック G-55)で接着して並列接続型バイモルフ部材を構成し，

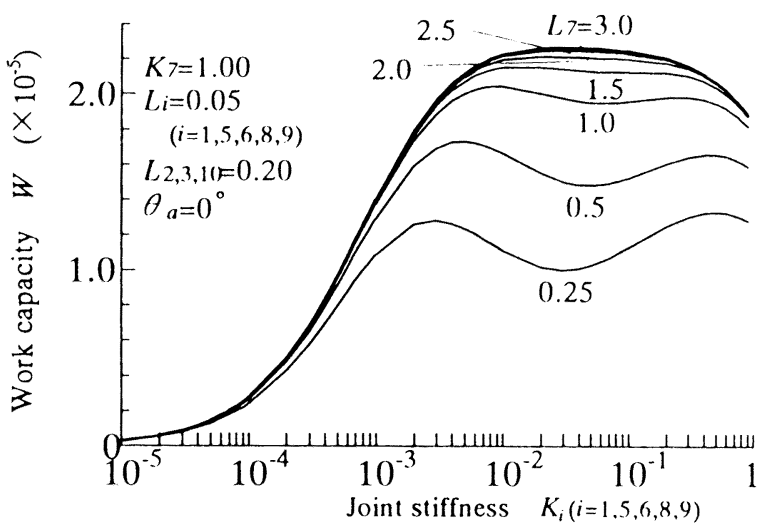

Fig.6 Change of work capacity with joint stiffness

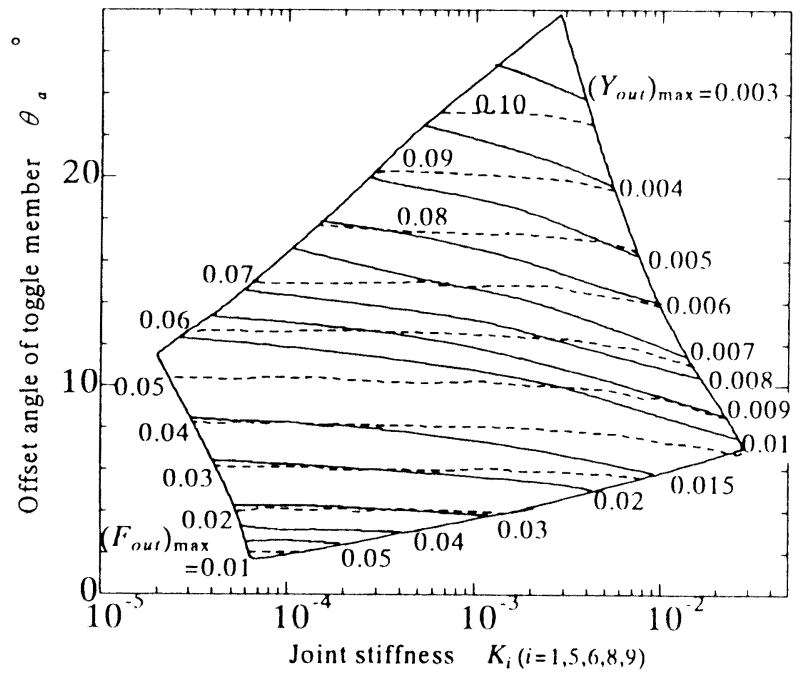

(a) Output force and displacement

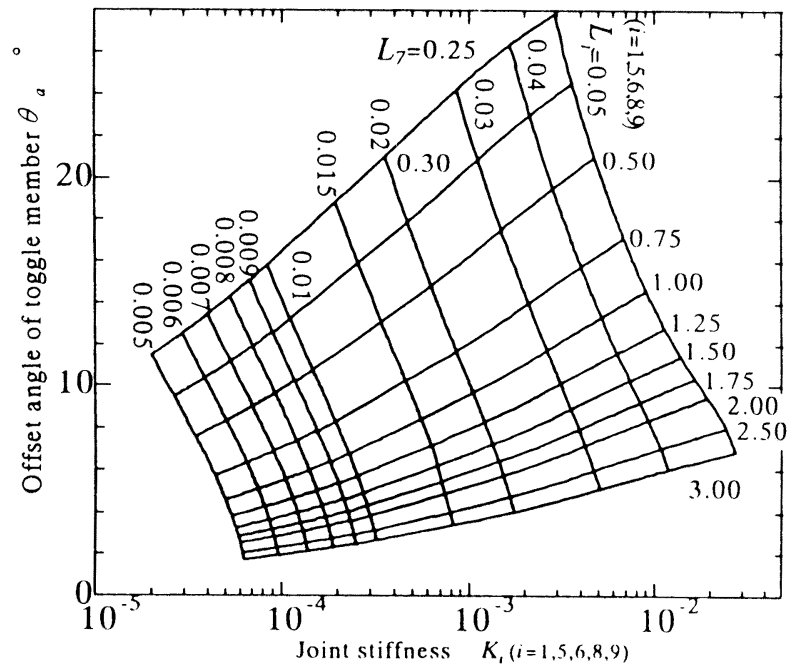

(b) Length of toggle and lever member

$K_{7}=1.00, L_{2,3,10}=0.2, \theta_{a}=0^{\circ},\left(X_{\text {in }}\right)_{\max }=7 \times 10^{-4},\left(F_{\text {in }}\right)_{\max }=2.0$

Fig.7 Reading off diagram for design 


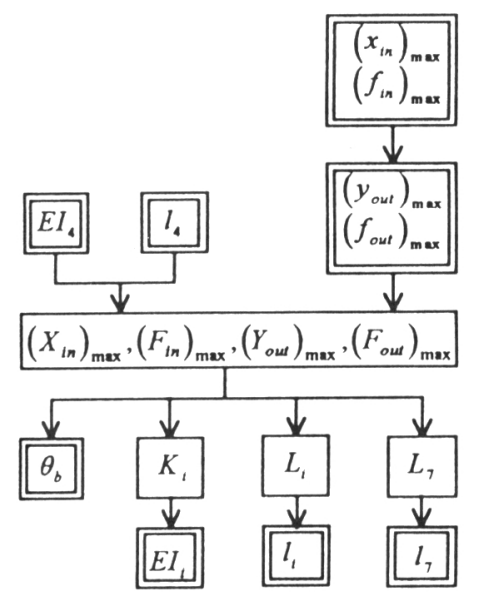

Fig.8 Design procedure

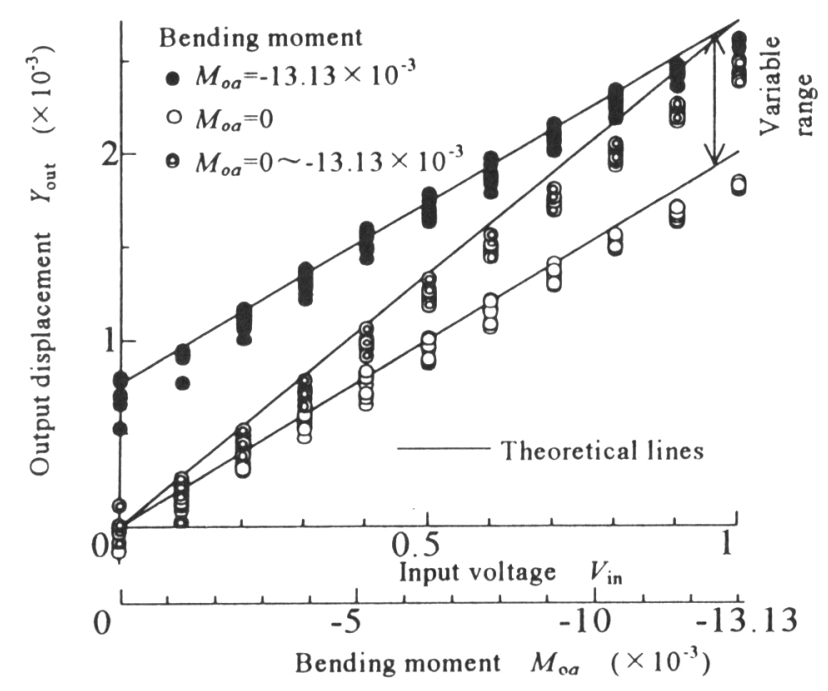

Fig.10 Change of output characteristic with bending moment of bimorph member in lever member

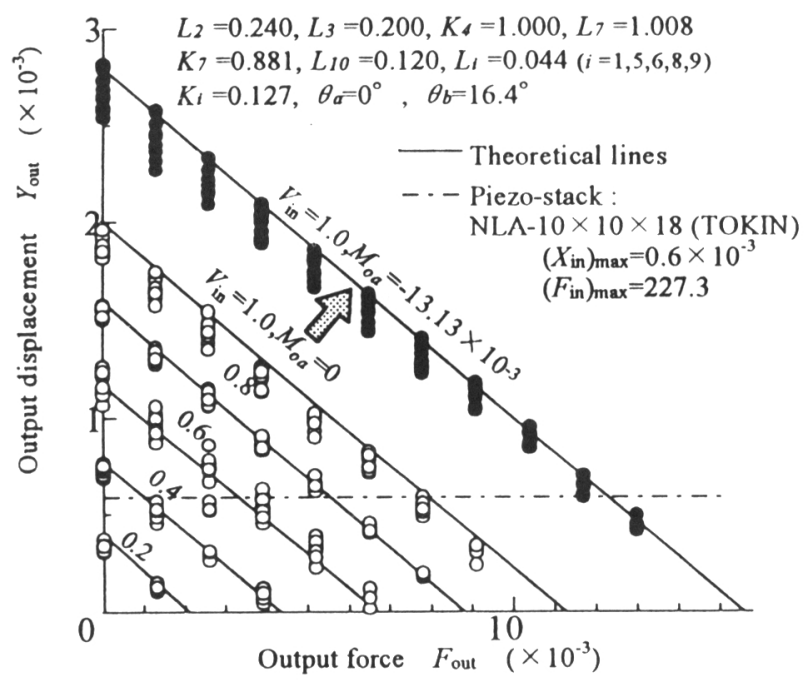

Fig.11 Change of boost effect with additional bending moment

両端をスリットに差込んで接着した後，ベースにばね押えで固定 した、入出力点は銅板 $(\mathrm{t} 3 \mathrm{~mm})$ を接着して補強した。積層型素子

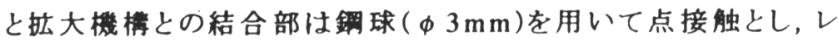
バー部が自由に傾き，常にレバー部材に垂直な力が作用するよ

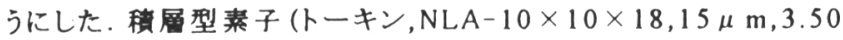
$\mathrm{kN} / 100 \mathrm{~V})$ には，ねじで与圧力を与えた。出力点の変位は静兆 容量型変位計 (岩通テクノシステム, ST-3701, ST-0518S17),

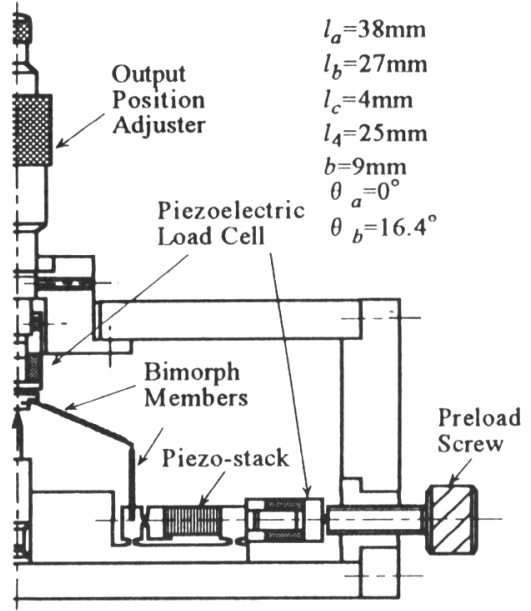

Fig.9 Experimental apparatus

発生力は圧電型ロードセル (KISTLER,9011A) で検出される.

無負荷状態で, 糟層型素子の印加電圧とレバー部材の発生 モーメントを変化したときの発生変位を図10 亿示す. 積層型素子 のヒステリシスは, 測定誤差の範囲内であった. 白丸印はレバー部の バイモルフ部材を駆動せず，ブースト勃果がないときを，また，黒 丸印はレバー部材にモーメント $M_{o n}=-13.13 \times 10^{-3}$ を発生させたと きを示寸.この籁囲内で印加電圧を調節寸れば, 任意の出力が 得られる. 二重丸印は下のMoa の值でモーメントを変化させた場 合である. 無負荷の状態でバイモルフ部材を駆動しない場合， 印加電圧の変化量が最低 $3.2 \mathrm{~V}$ で最小分解能 $1.57 \mu \mathrm{m}$ を得た。 機構は, 積層型素子の最大許容電圧の $80 \%$ までは線形性を 保った。慣性負荷をかけた場合の発生力と変位の関倸を図11 亿 示す. 1 点鎖線は主駆動源である楀層型素子の出力特性を示す. 榡層型素子の印加電压 $V_{\mathrm{in}}=1.0$ として, さらに部材に曲げモーメント を発生させれば, 矢印のように出力の変位と力が増加する。これは, バイモルフ部材の駆動により, 単に変位抬大だけでなく, 仕事能 力を增した出力特性に变えられることを示している

\section{7. 結論}

（1）部材曲师剛性をバイモルフ部材で可変にし，これを等価的 に増やして，その分部材を軽量化できる考方方を提案した。

(2) パイモルフ部材の発生するモーメントを変化させることで, 積層型素子の出力特性を任意に変化できる.

(3) 積層型素子による出力と, バイモルフ部材の出力重盢勃果 におけるトグル部の最適オフセット角はほぼ等しい.

（4）仕事能力を極大にする関節曲げ剛性と長さが存在する.

（5）無負荷時で, 最小分解能 $1.57 \mu \mathrm{m}$ を得た。

本研究の遂行に協力された町田利雄氏(現・アイシン精機(煳) 並びに琍富山村田製作所に感謝いたします。また，本研究の一 部は, 平成 3 年度文部省科学研究費補助金(一般研究 (c)) に よって行われたことを記し，関係各位に謝意を表します。

$$
\text { 考支献 }
$$

1) 圧電セラミックス(ピエソタタイト)，㮫村田製作所, P19-3 (1990).

2)樌層型圧電アクチュエー夕技術资料，(秝一キン，VR-014, Vol.01 (1989).

3) 清水成章, 河野英一:樌層型圧電アクチュエータ素子とその応用, 自動 化技術, 19, 9 (1987) 24 .

4) 抜山平一, 鈴木辰男: M型圧電振動子の振動姿態とその電気音繁定数, 通倍学会誌, 231 (1942) 367.

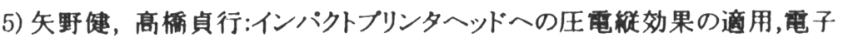
情報通信学会論文誌C, Vol.J71-C, 11 (1988) 1576. 